Hydrol. Earth Syst. Sci., 17, 3841-3852, 2013

www.hydrol-earth-syst-sci.net/17/3841/2013/

doi:10.5194/hess-17-3841-2013

(c) Author(s) 2013. CC Attribution 3.0 License.

\title{
A vital link: water and vegetation in the Anthropocene
}

\section{Gerten}

Potsdam Institute for Climate Impact Research, Research Domain 1: Earth System Analysis, 14473 Potsdam, Germany

Correspondence to: D. Gerten (gerten@ @ik-potsdam.de)

Received: 26 March 2013 - Published in Hydrol. Earth Syst. Sci. Discuss.: 8 April 2013

Revised: 14 August 2013 - Accepted: 23 August 2013 - Published: 9 October 2013

\begin{abstract}
This paper argues that the interplay of water, carbon and vegetation dynamics fundamentally links some global trends in the current and conceivable future Anthropocene, such as cropland expansion, freshwater use, and climate change and its impacts. Based on a review of recent literature including geographically explicit simulation studies with the process-based LPJmL global biosphere model, it demonstrates that the connectivity of water and vegetation dynamics is vital for water security, food security and (terrestrial) ecosystem dynamics alike. The water limitation of net primary production of both natural and agricultural plants already pronounced in many regions - is shown to increase in many places under projected climate change, though this development is partially offset by water-saving direct $\mathrm{CO}_{2}$ effects. Natural vegetation can to some degree adapt dynamically to higher water limitation, but agricultural crops usually require some form of active management to overcome it - among them irrigation, soil conservation and eventually shifts of cropland to areas that are less water-limited due to more favourable climatic conditions. While crucial to secure food production for a growing world population, such human interventions in water-vegetation systems have, as also shown, repercussions on the water cycle. Indeed, land use changes are shown to be the second-most important influence on the terrestrial water balance in recent times. Furthermore, climate change (warming and precipitation changes) will in many regions increase irrigation demand and decrease water availability, impeding rainfed and irrigated food production (if not $\mathrm{CO}_{2}$ effects counterbalance this impact - which is unlikely at least in poorly managed systems). Drawing from these exemplary investigations, some research perspectives on how to further improve our knowledge of human-watervegetation interactions in the Anthropocene are outlined.
\end{abstract}

\section{Introduction}

Plants need water to grow and survive - Ripl (2003) had a reason to characterise water as "the bloodstream of the biosphere". In turn, vegetation growth and productivity are closely coupled with the water cycle via the carbon cycle, with feedbacks traceable at the global scale (Hutjes et al., 1998; Donohue et al., 2007; Peel et al., 2010; Ito and Inatomi, 2012). Hence, one may pose the question how important vegetation-water interactions actually are in the Anthropocene, i.e. the present era characterised by pervasive anthropogenic transformations of the Earth's climate, land surface and ecosystems (Crutzen, 2003; Steffen et al., 2011). Among the many exponential upward trends that characterise the Anthropocene particularly since the 1950s are global warming (with impacts on vegetation dynamics and water cycles), the rapid increase in the land area taken into cultivation (Ellis, 2011), and the pronounced increase in water withdrawal and consumption (Vörösmarty et al., 2005). The latter is likely to further increase in the future and produce water stress in many regions (Arnell et al., 2011).

According to the vegetation-water coupling at process level, the trends in water and land use are interrelated. For example, expansion of cropland for the purpose of food production has often been accompanied by a promotion of water withdrawals for crop irrigation, especially in the course of the Green Revolution. In turn, such irrigation and land use changes in general alter evapotranspiration and eventually water availability, even at large scales (deFries and Eshleman, 2004; Gordon et al., 2005; Scanlon et al., 2007). Adding to this, the spatio-temporal dynamics of the terrestrial water cycle are intermingled with anthropogenic climate change (Bates et al., 2008). Besides the radiative effects of increasing atmospheric $\mathrm{CO}_{2}$ concentration, structural and physiological responses of (natural and agricultural) plants are likely to 
co-occur (as shown in numerous laboratory and field studies, e.g. Amthor, 1995; De Boer et al., 2011), with influences on water fluxes of potential significance at global scale (Gedney et al., 2006; Leipprand and Gerten, 2006). Hence, watervegetation relationships underlying these complex feedbacks are crucial for major environmental and societal issues such as climate change impacts, ecosystem integrity, water security, and food security.

To avert potentially adverse developments, humankind can still opt for sustainable pathways that could, e.g., minimise the magnitude of global warming, of water scarcity and of related impacts. These "planetary opportunities" (deFries et al., 2012), i.e. options to use natural resources in ecologically and socially more sustainable ways, include transitions to less water-intensive ways of production and consumption. Again, basic water-vegetation relationships are at the heart of many of those pathways - among them methods to increase plant water productivity, i.e. boost crop production per unit of water either withdrawn from rivers, reservoirs or groundwater ("blue water" used in irrigated agriculture) or evapotranspiring directly or through plants from the soil ("green water" on which rainfed agriculture depends; Falkenmark and Rockström, 2004). Crop water productivity and its regional pattern also underlies the quite sizeable global water savings associated with "virtual water trade" (Oki and Kanae, 2004; Konar et al., 2013). Virtual water is the blue and green water that has been consumed in export countries (in optimal cases characterised by water productivities higher than in import countries) and that is implicitly traded with agricultural and industrial commodities.

The objective of this paper is to reveal, and provide quantifications of, some core processes that link terrestrial vegetation, carbon and water dynamics and that appear to be relevant for the potential future evolution of the Earth's bioand hydrosphere as influenced by human activities characteristic of the Anthropocene. The purpose is to make explicit the role of water-vegetation and carbon interactions in global Anthropocene processes, based on a review of recent literature on this topic and illustrated by results from modelling studies selected to portray selected relationships and quantities. While the fundamentals of plant-water interactions have been extensively described in many papers and text books (e.g. Katul et al., 2007, and references therein), such an assessment/review has, to my knowledge, not yet been provided. A focus is on the following topics: (1) the current and potential future water limitation of terrestrial primary production (natural and agricultural plants, rainfed and irrigated) as controlled by global climate and its anticipated future changes; (2) the potential of farmers' water management options to increase crop production by reducing this water limitation to some extent; (3) the effect of climate and $\mathrm{CO}_{2}$ changes on irrigation requirements; and (4) the effect of human land cover/land use changes and water withdrawals on freshwater flows and resources. For each of these topics, some needs for future research (modelling studies in particular) are identified. I address the topics primarily from a global perspective, partly drawing from simulations (at $0.5^{\circ}$ spatial resolution) with the process-based LPJ and LPJmL Dynamic Global Vegetation Model (DGVM) published in earlier studies but revised, synthesised and expanded upon here. LPJmL is chosen here because it is one of very few global models that simulate plant growth and coupled carbon and water dynamics for both natural and agricultural vegetation in a single, physically consistent framework. As a prerequisite, the model has been validated in terms of its hydrological, vegetation-dynamical and biogeochemical features (e.g. Sitch et al., 2003; Gerten et al., 2004; Bondeau et al., 2007; Rost et al., 2008a; Biemans et al., 2009; Fader et al., 2010).

\section{Water limitation of terrestrial net primary production}

While it is generally known that plant growth and productivity depend on the availability and accessibility of water, the detailed physiological and ecohydrological mechanisms of plant water limitation are very complex (Rodríguez-Iturbe and Porporato, 2007). Globally, as assessed by Nemani et al. (2003), soil moisture is a main factor limiting terrestrial photosynthesis and net primary production (NPP). However, the severity and regional pattern of NPP water limitation depend on the co-limitation by temperature or radiation. Furthermore, it is controlled not solely by soil moisture but by the balance between soil moisture and atmospheric moisture deficit (determined by temperature, radiation and wind speed, and in turn determining potential transpiration). To capture these co-limitations, NPP water limitation can be defined as the ratio of actual (limited by soil moisture and plant hydraulic features) and potential canopy conductance (controlled by atmospheric conditions and photosynthesis rate, unlimited by soil moisture) of water and $\mathrm{CO}_{2}$ in the process of photosynthesis, as in Gerten et al. (2005, 2007).

Figure 1 illustrates that soil moisture and NPP water limitation are more or less decoupled in many regions. For example, NPP at high latitudes is hardly water-limited despite relatively low soil moisture, as in these regions temperature and/or radiation limit NPP stronger than does water. Also in the tropics, NPP is on average hardly water-limited, even though soil moisture temporarily (in dry seasons) falls below saturation levels. Correspondingly, climate change would affect the two variables differently. Increases (or declines) in soil moisture in response to projected future climate change do not necessarily mean that the productivity of concurrently existing vegetation becomes less (or more) water-limited. At high latitudes, for instance, the modelled increase in soil moisture hardly affects the water limitation of plants. The net physiological and structural $\mathrm{CO}_{2}$ effect is found to modify, or even cancel out, effects of temperature and precipitation on plant water limitation. Furthermore, the altered 


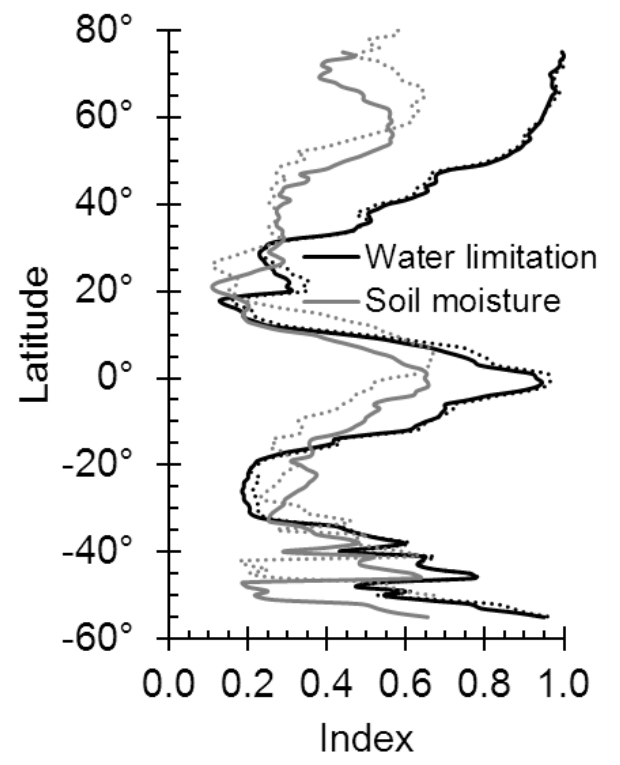

Fig. 1. Latitudinal pattern of soil moisture and NPP water limitation, presently (1971-2000 averages; solid lines) and in the future (2071-2100; dotted lines), simulated with the LPJ DGVM for potential natural vegetation. Future changes are the medians obtained under climate change scenarios from five General Circulation Models (SRES A2 emissions), including direct $\mathrm{CO}_{2}$ effects on plants. Both variables are plotted as indices scaled between 0 and 1: soil moisture relative to maximum water holding capacity $(0=$ dry $)$, water limitation relative to potential canopy conductance attainable under water-unlimited conditions $(0=$ completely waterlimited). Modified after Gerten et al. (2005, 2007).

hydroclimatic conditions induce shifts in the geographical distribution, composition and phenology of plants. For instance, in regions with decreasing soil moisture, vegetation will successively adapt to the drier conditions by e.g. compositional shifts and on average display a weaker NPP water limitation than the former, replaced vegetation would do.

Gerten et al. (2005) thus hypothesised a resilient behaviour of the terrestrial biosphere - "resilient" defined as the capacity of dynamic vegetation structural and compositional shifts in response to climatic and hydrologic change. Findings from plot-scale simulations and manipulation experiments combining different environmental change factors tend to support this conclusion. They show that manipulation of single factors (such as temperature, rainfall, $\mathrm{CO}_{2}$ concentration, nutrient supply) often provokes rather strong responses in key ecosystem features such as NPP, whilst multi-factor experiments can yield weaker responses as a net result of complex, nonlinear process interactions (Zhou et al., 2006; Luo et al., 2008).

Notwithstanding these possible equilibrating processes, satellite data show potentially strong and large-scale declines in NPP in response to lower soil moisture and increasing water limitation. Zhao and Running (2010) demonstrate that recent droughts and southern hemispheric drying trends have slowed down an increase in global terrestrial NPP that otherwise would be expected in response to temperature and $\mathrm{CO}_{2}$ rise, which happens to disagree with the hypothesised resilient behaviour. One possible explanation is that, currently, atmospheric $\mathrm{CO}_{2}$ concentration is still below a level that would buffer impacts of heatwaves or droughts. In general, establishing relationships between vegetation activity, water availability and climatic changes remains a complicated task (Huntingford et al., 2013; Ponce Campos et al., 2013), not least because land use changes interfere with such correlations (de Jong et al., 2013). Also, there are many factors that limit plants' response to $\mathrm{CO}_{2}$ rise (see below), including nutrient limitations and year-to-year variability of precipitation (Newingham et al., 2013) - although flux measurements and satellite observations now suggest that such responses are already happening in many environments (Donohue et al., 2013; Keenan et al., 2013).

Moreover, adaptive structural and especially genetic ecosystem changes are likely to occur only at longer time scales. Indeed, while there is (local) evidence for tree mortality and alterations to ecosystem structure in response to droughts (Anderegg et al., 2013) - sometimes even with multi-annual time lags due to complex processes related to vegetation architecture (Saatchi et al., 2013) - biomes seem to differ significantly with respect to their capacity and time scale to adapt to drought (Vicente-Serrano et al., 2013). Overall, spatially and temporally more detailed analyses of the interrelations of soil moisture, plant water stress, NPP and associated ecosystem changes in a changing global climate are required. Furthermore, a shortcoming of standalone DGVMs and also global hydrological models is that feedbacks from land cover and land use changes to the atmosphere are not represented (for the relevance of these feedbacks see e.g. Betts et al., 2007; Port et al., 2012). This is important, for example, in view of the fact that vegetation plays a key role in generating precipitation, which eventually is transported to other, distant regions (Gimeno et al., 2012; Keys et al., 2012). Fortunately, some DGVMs can be operated in an online mode that allows for the study of vegetation-atmosphere feedbacks (Krinner et al., 2005; Strengers et al., 2010), and Regional Climate Models can account for such interactions at smaller scales - though biases compared to observations often remain (e.g. Hemming et al., 2010).

\section{Water limitation of agricultural crops - and ways to overcome it}

Agricultural vegetation is governed by the same physiological and ecohydrological mechanisms as is natural vegetation, thus it is similarly prone to hydroclimatic changes. There is an important difference, though. On the one hand, farmers influence the distribution, structure, seasonality, water 
productivity and water limitation of crops through various forms of management, in order to maximise their production. On the other hand, other than in the case of potential natural vegetation, it is unlikely that the composition and distribution of cultivated crops will shift in response to climatic and hydrologic changes without direct human intervention (such as altered crop varieties, cropping patterns, irrigation, etc.).

The global modelling study by Rost et al. (2009) quantifies the water limitation of agricultural crops (computed analogous to Gerten et al. (2007) and broadly reflecting spatial patterns as presented in Fig. 1 for natural vegetation), the extent to which this limitation is presently overcome by irrigation in some regions, and by how much it could be diminished further through specific on-farm management practices especially in rainfed regions (see Fig. 2). While measures to overcome e.g. nutrient limitations were not addressed, the latter practices account for avoidance of soil evaporation - which keeps more water in the soil column for potential use in the process of transpiration and biomass build-up - and for collection ("harvesting") of water and its later use as supplemental irrigation during dry spells. Present irrigation evidently minimises crop water limitation in a number of countries, while (rainfed) crop yields could be boosted significantly further if the considered management options were actually implemented (Fig. 2b and c). The LPJmL simulations suggest that avoidance of $25 \%$ of soil evaporation and harvesting and later use of $25 \%$ of (sub)surface runoff on the world's cropland would increase global crop production by nearly a fifth (Rost et al., 2009). In some regions, gains of similar magnitude could be achieved through expansion of irrigation areas and/or increased irrigation efficiency.

However, these yield increases would probably be too small to meet the requirements of a prospective world population of 9 or 10 billion people. Along these lines, in an analysis of hypothetical food self-sufficiency and trade dependency of countries, Gerten et al. (2011) and Fader et al. (2013) found that many countries may not be able to produce the food required for a given diet with their domestic arable land and water resources; climate and demographic change would increase the implied trade dependency even more. This will be the case even if the green water resource (soil water on cropland) is accounted for - a resource that adds substantially to the blue water usable for crop irrigation (Rost et al., 2008a; Rockström et al., 2009a). Note that these studies considered spatial and temporal differences in crop water productivity as controlled by climate and crop management, which determine how many calories can be produced in the different regions with the available water resources. The productivity patterns also underlie the quantities of water "virtually" traded internationally along with crop-based and other products (Hanasaki et al., 2010; Siebert and Döll, 2010; Fader et al., 2011; Hoekstra and Mekonnen, 2012). Eventually, water-vegetation linkages in export countries relative to those in import countries determine whether and how much water can be "saved" globally through trade.
An optimised virtual water trade can thus reduce water withdrawal in water-scarce regions and avoid cropland expansion that might otherwise be necessary to access more blue and green water, respectively. To my knowledge, so far only one study has explored possible changes in future global trade and their effects on global water savings (Konar et al., 2013), yet internally consistent modelling and balancing schemes for such assessments are still under development (Schmitz et al., 2013).

The above and other studies also clearly demonstrate that (green) water availability and land use are closely connected, complicating trade-offs in land use and water use, respectively (Beringer et al., 2011). Accordingly, the "planetary boundaries" of water consumption and land use, which should not be exceeded to avoid deleterious impacts on Earth system functioning and human societies, are tightly linked as well. The provisional definition and quantification of such planetary boundaries (Rockström et al., 2009b) thus require refinement by means of spatially explicit calculation of local water and land limits and opportunities to stay below them (see Gerten et al., 2013).

\section{Effects of climate and $\mathrm{CO}_{2}$ change on irrigation}

As noted above, climate change is likely to affect the water limitation of natural and agricultural vegetation via impacts on soil moisture and atmospheric water demand, complicated by direct plant responses to rising atmospheric $\mathrm{CO}_{2}$ concentration. In simulations using input from three climate models (forced by the SRES A2 emissions scenario), Rost et al. (2009) find that climate change alone would increase water limitation in many regions (in response to precipitation declines and higher temperatures) and, thus, decrease total global crop production. They also show that this impact could be balanced by the direct beneficial $\mathrm{CO}_{2}$ effects on crop water use efficiency and production (as in the case of natural vegetation) - an effect which is relevant primarily for $\mathrm{C} 3$ plants, whose photosynthetic pathway is sensitive to ambient $\mathrm{CO}_{2}$ concentration. Analogously, Konzmann et al. (2013) show that the irrigation requirement - defined as the amount of (blue) water needed to ease NPP water limitation of crops - of present irrigation areas will increase in many regions in response to climate change (higher temperatures and in some regions such as the Mediterranean also lower precipitation). In contrast, global irrigation demand would decrease by 9-19\% (range from 19 spatially explicit climate change scenarios) if the crop responses to elevated $\mathrm{CO}_{2}$ were accounted for, according to LPJmL simulations (Fig. 3).

Hence, $\mathrm{CO}_{2}$ effects are potentially a major factor for future vegetation productivity, water availability and water stress - relevant not only for potential water savings but also for boosting crop yields as required for an increasing world population. Unfortunately, it is highly uncertain to what extent 
a. Present water limitation
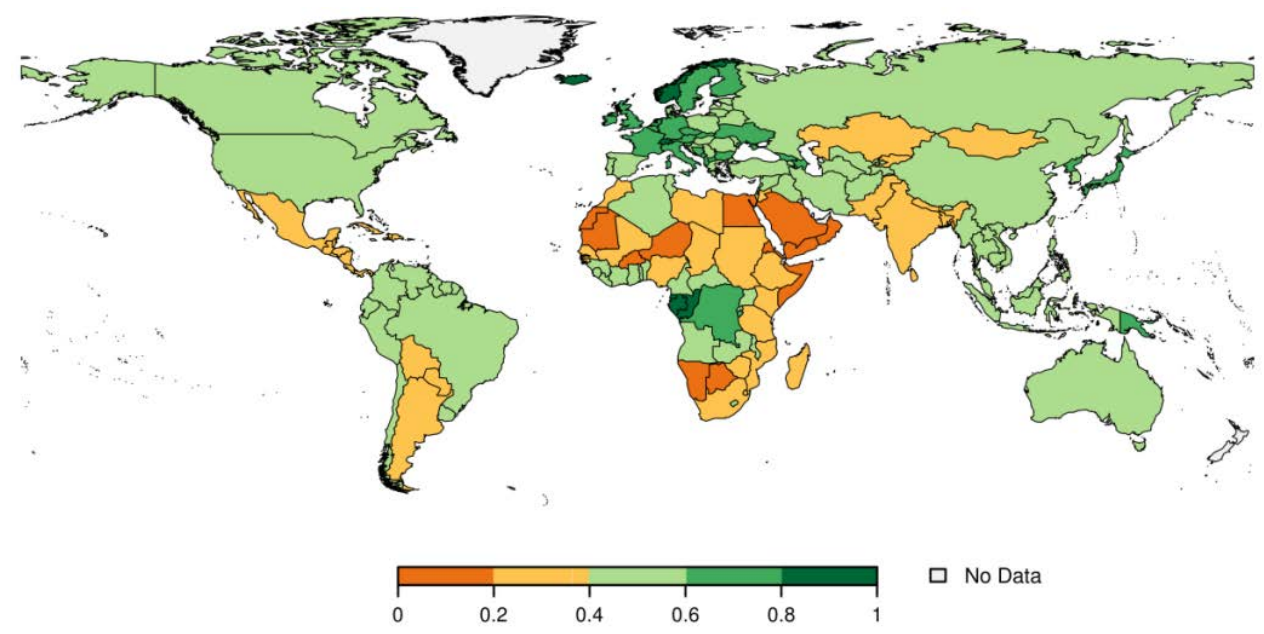

b. Production increase through present irrigation

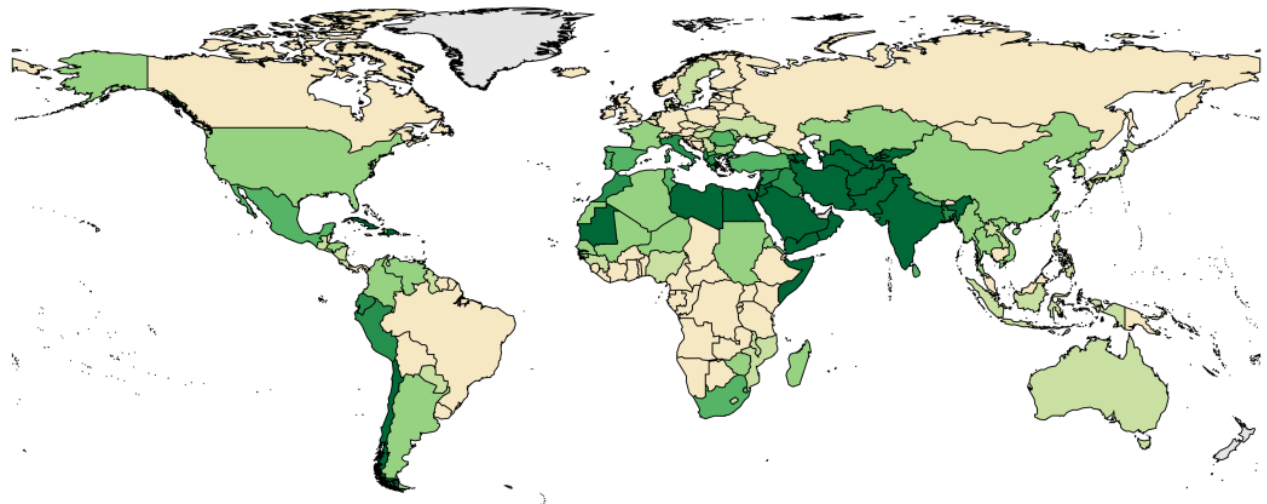

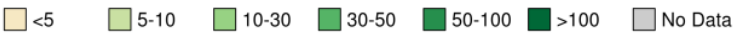

c. Possible further production increase through on-farm management

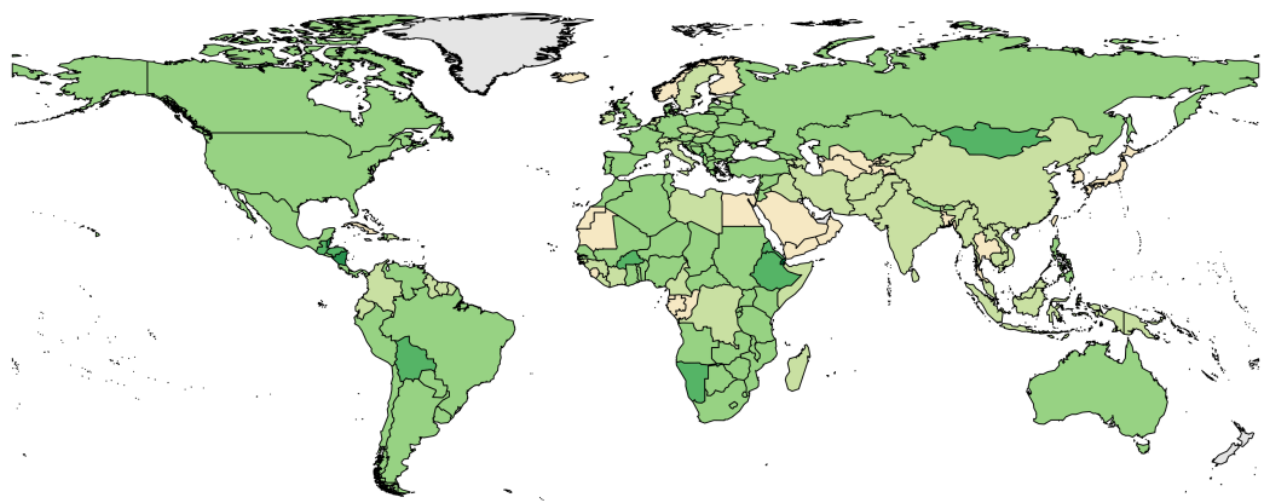

Fig. 2. (a) LPJmL-computed country average NPP water limitation during the growing season on current cropland (1971-2000), expressed in terms of the water limitation index also used in Fig. 1. (b) Increase in crop production currently achieved through irrigation (assuming that irrigation demand can always be met on areas currently equipped for irrigation). (c) Potential further increase in rainfed and irrigated crop production through both collection of $25 \%$ of runoff from cropland and avoidance of $25 \%$ of soil evaporation. For calculation procedure and more detailed maps see Rost et al. (2009). 

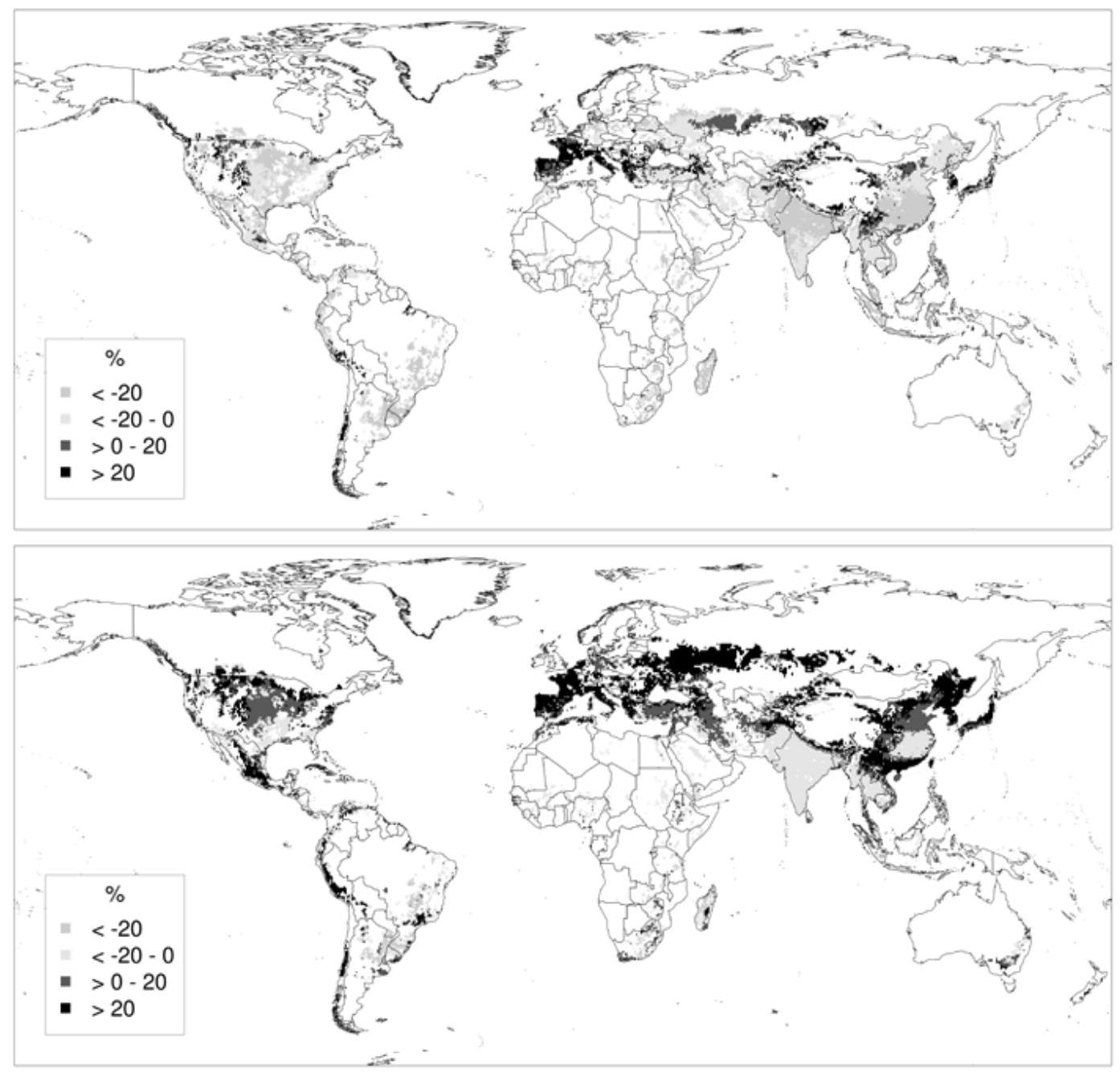

Fig. 3. Areas currently equipped for irrigation that are simulated to experience an increase or a decrease in irrigation demand by the 2080 s. Shades of grey indicate the percentage change in irrigation requirements relative to 1971-2000, portrayed as the median across 19 climate models used to force the LPJmL model. Top panel: including effects of rising atmospheric $\mathrm{CO}_{2}$ content; bottom panel: excluding these effects. The $\mathrm{CO}_{2}$ effect would be fully realised only if unconstrained by factors such as nutrient limitation - hence, the top panel represents an optimistic scenario assuming absence of such limitations, possibly achievable through intensive management. Maps were modified after Fig. 2 in Konzmann et al. (2013).

the beneficial $\mathrm{CO}_{2}$ effects will be suppressed by other environmental factors. Debates are ongoing on the strength of this effect and its subsequent influences on the global water cycle and climate (e.g. Tubiello et al., 2007; Cao et al., 2009; Friend, 2010). DGVMs such as LPJmL reproduce well the plant responses observed in open-field Free Air $\mathrm{CO}_{2} \mathrm{En}$ richment (FACE) experiments (Hickler et al., 2008), and the implemented conductance and transpiration schemes are in line with accepted theory for stomatal behaviour under $\mathrm{CO}_{2}$ enriched conditions (Medlyn et al., 2011). Nevertheless, besides improving the representation of plant-water dynamics in global models (see Sect. 6), more work is required on the modelling of processes that might constrain the $\mathrm{CO}_{2}$ response in the future - first and foremost on herbivory and on nutrient limitation in both natural ecosystems (Zaehle and Dalmonech, 2011) and agricultural systems (Long et al., 2006). For example, it is perplexing that crops appear to be significantly less responsive to $\mathrm{CO}_{2}$ enrichment in FACE experiments than in chambers (based on which models are usually parameterised). Understanding why major crops fail to achieve yield improvements as high as those observed in chambers is of immediate importance for future food supply, as many millions of people might depend on whether or not these improvements can be attained in a warming climate (Leakey et al., 2009). More systematic assessments of the many other ways to boost crop yields, such as agricultural intensification (Edgerton, 2009; Foley et al., 2011), are required, but they need to account more explicitly for water 
availability as a production constraint (Mueller et al., 2012; Elliott et al., 2013). Socio-hydrological studies of humanenvironment coevolution pathways would shed light on (future) mutual dynamics of land and water resources and human societies' resource needs, considering resource limitations, options to improve efficiencies, and possible rebound effects according to Jevons' paradox, where increased resource use efficiency leads to increased resource consumption (Jevons, 1866).

\section{Effects of land cover and land use changes in the global water balance}

If actually required to increase global food production in the future (see above), expansion of cropland - either rainfed or irrigated - is likely to affect the water cycle. Gordon et al. (2005), Piao et al. (2007) and Rost et al. (2008a,b) demonstrate that historic land cover conversions and water withdrawals have already noticeably changed the partitioning of terrestrial precipitation into evapotranspiration and runoff. Human land cover change, especially deforestation, is often associated with lower rooting depths, lower interception losses and shorter growing periods, altogether resulting in higher evapotranspiration - notwithstanding exceptions to this average signal in specific locations. Thus, compared to a situation without any human land use (i.e. a situation with potential natural vegetation only), current global river discharge was estimated to be $5 \%$ higher according to LPJmL simulations (Rost et al., 2008b). Moreover, in the absence of irrigation, discharge to the world oceans would be at least $0.6 \%$ higher than presently. Pokhrel et al. (2012) suggest an even higher percentage, in which case a contribution to sea level rise cannot be ruled out (but see Konikow, 2012). Similarly, Gerten et al. (2008) suggest that the collective effect of land cover and land use changes over the past century was an increase in global discharge by $\sim 6 \mathrm{~km}^{3} \mathrm{yr}^{-2}$; this impact ranks second after the predominant impact of precipitation fluctuations and trends. Meanwhile, a widespread "global stilling" (declining near-surface wind speed) is another candidate for changes in potential and actual evapotranspiration, with repercussions on river discharge (McVicar et al., 2012).

Since transpiration - which contributes most to total land evapotranspiration (Jasechko et al., 2013) - occurs through the stomata of plants which, in turn, are regulated by atmospheric $\mathrm{CO}_{2}$ concentration (see above), Gedney et al. (2006) suggest that the recent rise in $\mathrm{CO}_{2}$ has already left a discernible impact on global river discharge. Their hypothesis is that reduced transpiration due to the physiological $\mathrm{CO}_{2}$ effect is the main cause of a supposed increase in global discharge. While other authors (Peel and McMahon, 2006) point to data issues regarding this conclusion, Gerten et al. (2008) are in principle supportive of Gedney et al.'s (2006) conclusion. However, the magnitude of this increase is rather small in the underlying LPJmL simulations $\left(\sim 4 \mathrm{~km}^{3} \mathrm{yr}^{-2}\right)$.
An explanation is that the structural $\mathrm{CO}_{2}$ effect - an increase in biomass and evapotranspiration seen in some semiarid regions where vegetation cover slightly expands - partly outweighs the physiological effect that reduces transpiration due to stomatal closure. The balance between physiological and structural $\mathrm{CO}_{2}$ effects requires a more systematic investigation, though - also in the light of findings by Piao et al. (2007), who find with another DGVM that the net effect is a small decrease in global discharge.

While the attribution of drivers of past changes in discharge has been refined more recently (e.g. Dai et al., 2009; Alkama et al., 2010, 2011), it appears that the precise contribution of natural vs. anthropogenic drivers, and of changes in vegetation, to variations and trends in global discharge currently cannot be quantified on solid grounds. Even the existence of an upward global trend is hardly detectable with confidence. The main reason is - besides uncertainties in other drivers - that the uncertainty in global precipitation and also discharge data is so high (due to incomplete observation networks and time series) that different datasets disagree not only in terms of the magnitude but even in terms of the signs of the global trend (range in 20th century global discharge trend from four precipitation datasets: -4 to $+8 \mathrm{~km}^{3} \mathrm{yr}^{-2}$; Gerten et al., 2008). Similarly, estimates of long-term average global runoff and evapotranspiration computed by global hydrological, land surface and vegetation models exhibit a very large spread in the order of $\pm 20 \%$ (Haddeland et al., 2011). This calls for systematic model intercomparisons, including identification of model structural differences and knowledge gaps. Also, efforts are needed to better reconcile differences between model results and observations (Dai et al., 2009; Jung et al., 2010; Dai, 2013; Sterling et al., 2013; Douville et al., 2013) and to constrain model results by hydrological, meteorological and biogeochemical data (Milly and Dunne, 2002; Beer et al., 2007). However, calibration and tuning of individual variables is problematic in coupled vegetation-water models such as $\mathrm{LPJmL}$, as this may compromise the simulation quality of other, untuned hydrological, biogeochemical and vegetation-related variables. Detailed mesoscale inspection of forces of hydrologic changes, of their uncertainty, and of the role of vegetation-water interactions is required as well, in order to complement coarserscale global assessments (Destouni et al., 2013; Immerzeel and Bierkens, 2012).

Notwithstanding the uncertainties associated with the past and present global water balance, many studies clearly indicate a rise in future global discharge in response to the radiative (intensification of the hydrological cycle along with global warming) and physiological vs. structural effects of further increasing atmospheric $\mathrm{CO}_{2}$ content (see Bates et al., 2008). To the extent that anthropogenic land use changes and water withdrawals will continue, they will additionally affect the future global water cycle. Systematic quantifications of the latter effects are pending, not least because it remains an open question whether more cropland will be cultivated in 
the future, what regions will face a deforestation or afforestation, and how much cropland will be irrigated.

\section{Conclusions}

The exemplary findings reviewed and discussed herein demonstrate that vegetation, water, climate and human activities are closely linked, and that these links underlie some of the global trends characteristic of the Anthropocene. It is shown that vegetation dynamics and productivity are in many regions controlled by water availability, that this water limitation is likely to change in response to anthropogenic climate change (via complex interactions, e.g. involving plant responses to $\mathrm{CO}_{2}$ ), that part of the water limitation of agricultural plants can be overcome by more efficient water use whereas some expansion of irrigated or rainfed cropland may be inevitable as an additional measure to meet future food requirements, and that such irrigation, land use and land cover changes feed back significantly to water resources and water cycles. The two latter points demonstrate that wise management of green and blue water is needed, including increases in crop water productivity - a water-vegetation link that is key to meeting the challenge of water and food security in the Anthropocene. Indeed, implementation and revitalisation of such "more crop per drop" practices in the context of a current paradigm shift towards "soft-path" strategies is gaining increasing importance for global water and food security (Gleick, 2000; Molden, 2007; McIntyre et al., 2008). Eventually, new and old ways of sustainable water management need to be further explored in the modern Anthropocene - there was and still is a diversity of alternative perceptions and modes of water use, which altogether could enrich the dominating contemporary focus on quantifiable material aspects of water (Gerten, 2010; Linton, 2011). Such new perspectives account for co-benefits across the waterfood-energy nexus (Hoff, 2011) and are ideally informed by a new water ethos that values water and its many functions more comprehensively than in previous decades (Falkenmark and Folke, 2002; Groenfeldt and Schmidt, 2013). Systematic exploration of such opportunities in both theory and practice would help frame climatic, ecologic and hydrologic changes within their wider cultural dimensions (Adger et al., 2013) and acknowledge the crucial role of water and vegetation for the well-being and survival of human societies (Folke et al., 2011).

This review includes selected results from a DGVM including a representation of human land use and management - i.e. a model type suited to simulate coupled water, carbon and vegetation dynamics for natural and agricultural systems at a global scale. While a discussion of the fundamental water-plant interactions embedded in this particular model (as detailed e.g. in Gerten et al., 2007) is not possible within the scope of this paper, it has to be stressed that DGVMs represent these dynamics in different ways, both in terms of considered processes and in terms of the level of complexity in representing these processes and their interplay. Hence, there is a need for systematic intercomparison of structures and simulation results of different DGVMs, for thorough evaluations of model results against (newly available) datasets, as mentioned in section 5, and eventually for model improvements based on such evaluations and on new observational data products (see e.g. Beer et al., 2010). Intercomparisons of diverse DGVM features have been performed several times (e.g. Cramer et al., 2001; Luo et al., 2008; Piao et al., 2013), but only recently have models of different types (DGVMs, global hydrological models and land surface models) been compared in a systematic fashion (Haddeland et al., 2011; Davies et al., 2013; Deryng et al., 2013; also see Rosenthal and Tomeo, 2013). Results from those studies suggest that confidence in simulations of future water availability and crop production is relatively low, not least because simulated plant responses to $\mathrm{CO}_{2}$ rise diverge significantly among those models. This evidence reinforces the need for better reconciliation of model results with observational time series, and for enhancing spatio-temporal databases of key Anthropocene processes.

Acknowledgements. This paper was supported by the Sixth and Seventh Framework Programme of the European Communities (projects WATCH and ERMITAGE, grant agreements no. 036946 and 265170, respectively) and the BMBF's project "Nachhaltiges Wassermanagement in einer Globalisierten Welt". I am grateful to Jonas Jägermeyr and Markus Konzmann for their assistance in preparing the figures, and Stefan Hagemann and three anonymous referees for constructive comments on the earlier discussion paper.

Edited by: M. Sivapalan

\section{References}

Adger, W. N., Barnett, J., Brown, K., Marshall, N., and O’Brien, K.: Cultural dimensions of climate change impacts and adaptation, Nat. Clim. Change, 3, 112-117, doi:10.1038/nclimate1666, 2013.

Alkama, R., Kageyama, M., and Ramstein, G.: Relative contributions of climate change, stomatal closure, and leaf area index changes to 20th and 21st century runoff change: a modelling approach using the Organizing Carbon and Hydrology in Dynamic Ecosystems (ORCHIDEE) land surface model, J. Geophys. Res., 115, D17112, doi:10.1029/2009JD013408, 2010.

Alkama, R., Decharme, B., Douville, H., and Ribes, A.: Trends in global and basin-scale runoff over the late twentieth century: methodological issues and sources of uncertainty, J. Climate, 24, 3000-3014, 2011.

Amthor, J. S.: Terrestrial higher-plant response to increasing atmospheric $\left[\mathrm{CO}_{2}\right]$ in relation to the global carbon cycle, Global Change Biol., 1, 243-274, 1995.

Anderegg, W. R. L., Kane, J. M., and Anderegg, L. D. L.: Consequences of widespread tree mortality triggered by drought and temperature stress, Nat. Clim. Change, 3, 30-36, 2013. 
Arnell, N. W., van Vuuren, D. P., and Isaac, M.: The implications of climate policy for the impacts of climate change on global water resources, Global Environ. Change, 21, 592-603, 2011.

Bates, B. C., Kundzewicz, Z. W., Wu, S., and Palutikof, J. P. (Eds.): Climate Change and Water, IPCC Tech. Paper VI, IPCC Secretariat, Geneva, 2008.

Beer, C., Lucht, W., Gerten, D., Thonicke, K., and Schmullius, C.: Effects of freeze-thaw processes on biomass in Siberia, Global Biogeochem. Cy., 21, GB1012, doi:10.1029/2006GB002760, 2007.

Beer, C., Reichstein, M. , Tomelleri, E., Ciais, P., Jung, M., Carvalhais, N., Rodenbeck, C., Arain, M. A., Baldocchi, D., Bonan, G. B., Bondeau, A., Cescatti, A., Lasslop, G., Lindroth, A., Lomas, M., Luyssaert, S., Margolis, H., Oleson, K. W., Roupsard, O., Veenendaal, E., Viovy, N., Williams, C., Woodward, F. I., and Papale, D.: Terrestrial gross carbon dioxide uptake: global distribution and covariation with climate, Science, 329, 834-838, 2010

Beringer, T., Lucht, W., and Schaphoff, S.: Bioenergy production potential of global biomass plantations under environmental and agricultural constraints, Global Change Biol. Bioen., 3, 299-312, 2011.

Betts, R., Boucher, O., Collins, M., Cox, P. M., Falloon, P. D., Gedney, N., Hemming, D. L., Huntingford, C., Jones, C. D., Sexton, D. M. H., and Webb, M. J.: Projected increase in continental runoff due to plant responses to increasing carbon dioxide, $\mathrm{Na}$ ture, 448, 1037-1041, 2007.

Biemans, H., Hutjes, R., Kabat, P., Strengers, B., Gerten, D., and Rost, S.: Impacts of precipitation uncertainty on discharge calculations for main river basins, J. Hydrometeorol., 10, 1011-1025, 2009.

Bondeau, A., Smith, P. C., Zaehle, S., Schaphoff, S., Lucht, W., Cramer, W., Gerten, D., Lotze-Campen, H., Müller, C., Reichstein, M., and Smith, B: Modelling the role of agriculture for the 20th century global terrestrial carbon balance, Global Change Biol., 13, 679-706, 2007.

Cao, L., Bala, G., Caldeira, K., Nemani, R., and Ban-Weiss, G.: Climate response to physiological forcing of carbon dioxide simulated by the coupled Community Atmosphere Model (CAM3.1) and Community Land Model (CLM3.0), Geophys. Res. Lett., 36, L10402, doi:10.1029/2009GL037724, 2009.

Cramer, W., Bondeau, A., Woodward, F. I., Prentice, I. C., Betts, R. A., Brovkin, V., Cox, P. M., Fisher, V., Foley, J., Friend, A. D., Kucharik, C., Lomas, M. R., Ramankutty, N., Sitch, S., Smith, B., White, A., and Young-Molling, C.: Global response of terrestrial ecosystem structure and function to $\mathrm{CO}_{2}$ and climate change: results from six dynamic global vegetation models, Global Change Biol., 7, 357-373, 2001.

Crutzen, P. J.: Geology of mankind, Nature, 415, p. 23, 2003.

Dai, A.: Increasing drought under global warming in observations and models, Nat. Clim. Change, 3, 52-58, 2013.

Dai, A., Qian, T., Trenberth, K. E., and Milliman, J. D.: Changes in continental freshwater discharge from 1948 to 2004, J. Climate, 22, 2773-2792, 2009.

Davie, J. C. S., Falloon, P. D., Kahana, R., Dankers, R., Betts, R., Portmann, F. T., Clark, D. B., Itoh, A., Masaki, Y., Nishina, K., Fekete, B., Tessler, Z., Liu, X., Tang, Q., Hagemann, S., Stacke, T., Pavlick, R., Schaphoff, S., Gosling, S. N., Franssen, W., and Arnell, N.: Comparing projections of future changes in runoff and water resources from hydrological and ecosystem models in ISI-MIP, Earth Syst. Dynam. Discuss., 4, 279-315, doi:10.5194/esdd-4-279-2013, 2013.

De Boer, H. J., Lammertsma, E. I., Wagner-Cremer, F., Dilcher, D. L., Wassen, M. J., and Dekker, S. C.: Climate forcing due to optimization of maximal leaf conductance in subtropical vegetation under rising $\mathrm{CO}_{2}$, P. Natl. Acad. Sci. USA, 108, 4041-4046, 2011.

DeFries, R. and Eshleman, K. N.: Land-use change and hydrologic processes: a major focus for the future, Hydrol. Process., 18, 2183-2186, 2004

DeFries, R., Ellis, E. C., Chapin III, F. S., Matson, P. A., Turner II, B. L., Agrawal, A., Crutzen, P. J., Field, C., Gleick, P., Kareiva, P. M., Lambin, E., Liverman, D., Ostrom, E., Sanchez, P. A., and Syvitski, J.: Planetary opportunities: a social contract for global change science to contribute to a sustainable future, BioScience, 62, 603-606, 2012.

de Jong, R., Schaepman, M. E., Furrer, R., de Bruin, S., and Verburg, P. H.: Spatial relationship between climatologies and changes in global vegetation activity, Global Change Biol., 19, 1953-1964, 2013.

Deryng, D., Ruane, A. C., Folberth, C., Müller, C., Pugh, T. A. M., Schmid, E., Boote, K. J., Gerten, D., Jones, J. W., Olin, S., Schaphoff, S., Yang, H., and Rosenzweig, C.: Disentangling uncertainties in future crop water productivity under climate change, P. Natl. Acad. Sci. USA, submitted, 2013.

Destouni, G., Jaramillo, F., and Prieto, C.: Hydroclimatic shifts driven by human water use for food and energy production, Nat. Clim. Change, 3, 213-217, doi:10.1038/nclimate1719, 2013.

Donohue, R. J., Roderick, M. L., and McVicar, T. R.: On the importance of including vegetation dynamics in Budyko's hydrological model, Hydrol. Earth Syst. Sci., 11, 983-995, doi:10.5194/hess11-983-2007, 2007.

Donohue, R. J., Roderick, M. L., McVicar T. R., and Farquhar, G. D.: Impact of $\mathrm{CO}_{2}$ fertilization on maximum foliage cover across the globe's warm, arid environments, Geophys. Res. Lett., 40, 3031-3035, 2013

Douville, H., Ribes, A., Decharme, B., Alkama, R., and Sheffield, J.: Anthropogenic influence on multidecadal changes in reconstructed global evapotranspiration, Nat. Clim. Change, 3, 59-62, 2013.

Edgerton, M.: Increasing crop productivity to meet global needs for feed, food, and fuel. Plant Phys., 149, 7-13, 2009.

Elliott, J., Deryng, D., Müller, C., Frieler, K., Konzmann, M., Gerten, D., Glotter, M., Flörke, M., Wada, Y., Eisner, S., Folberth, C., Foster, I., Gosling, S. N., Haddeland, I., Khabarov, N., Ludwig, F., Masaki, Y., Olin, S., Rosenzweig, C., Ruane, A. C., Satoh, Y., Schmid, E., Stacke, T., Tang, Q., and Wisser, D.: Constraints and potentials of future irrigation water availability on agricultural production under climate change, P. Natl. Acad. Sci. USA, submitted, 2013.

Ellis, E. C.: Anthropogenic transformation of the terrestrial biosphere, Philos. T. Roy. Soc. A, 369, 1010-1035, 2011.

Fader, M., Rost, S., Müller, C., Bondeau, A., and Gerten, D.: Virtual water content of temperate cereals and maize: present and potential future patterns, J. Hydrol., 384, 218-231, 2010.

Fader, M., Gerten, D., Thammer, M., Heinke, J., Lotze-Campen, H., Lucht, W., and Cramer, W.: Internal and external green-blue agricultural water footprints of nations, and related water and land 
savings through trade, Hydrol. Earth Syst. Sci., 15, 1641-1660, doi:10.5194/hess-15-1641-2011, 2011.

Fader, M., Gerten, D., Krause, M., Lucht, W., and Cramer, W.: Spatial decoupling of agricultural production and consumption: quantifying dependence of countries on food imports due to domestic land and water constraints, Environ. Res. Lett., 8, 014046, doi:10.1088/1748-9326/8/1/014046, 2013.

Falkenmark, M. and Folke, C.: The ethics of socio-ecohydrological catchment management: towards hydrosolidarity, Hydrol. Earth Syst. Sci., 6, 1-10, doi:10.5194/hess-6-1-2002, 2002.

Falkenmark, M. and Rockström, J.: Balancing Water for Humans and Nature, Earthscan, London, 2004.

Foley, J. A., Ramankutty, N., Brauman, K. A., Cassidy, E. S., Gerber, J. S., Johnston, M., Mueller, N. D., O’Connell, C., Ray, D. K., West, P. C., Balzer, C., Bennett, E. M., Carpenter, S. R., Hill, J., Monfreda, C., Polasky, S., Rockström, J., Sheehan, J., Siebert, S., Tilman, D., and Zaks, D. P. M.: Solutions for a cultivated planet, Nature, 478, 337-342, 2011.

Folke, C., Jansson, Å., Rockström, J., Olsson, P., Carpenter, S. R., Chapin III, F. S., Crépin, A.-S., Daily, G., Danell, K., Ebbesson, J., Elmqvist, T., Galaz, V., Moberg, F., Nilsson, M., Österblom, H., Ostrom, E., Persson, A., Peterson, G., Polasky, S., Steffen, W., Walker, B., and Westley, F.: Reconnecting to the biosphere, Ambio, 40, 719-738, 2011.

Friend, A. D.: Terrestrial plant production and climate change, J. Exp. Bot., 61, 1293-1309, 2010.

Gedney, N., Cox, P. M., Betts, R. A., Boucher, O., Huntingford, C., and Stott, P. A.: Detection of a direct carbon dioxide effect in continental river runoff records, Nature, 439, 835-838, 2006.

Gerten, D.: Hydrolatry in early European religions and Christian syncretism: how water transcends religions and epochs, in: Idea of Water from Ancient Societies to the Modern World, A History of Water Series II, Vol. 1, edited by: Tvedt, T., and Østigård, T., I. B. Tauris, London, 323-342, 2010a.

Gerten, D., Schaphoff, S., Haberlandt, U., Lucht, W., and Sitch, S.: Terrestrial vegetation and water balance: hydrological evaluation of a dynamic global vegetation model, J. Hydrol., 286, 249-270, 2004.

Gerten, D., Lucht, W., Schaphoff, S., Cramer, W., Hickler, T., and Wagner, W.: Hydrologic resilience of the terrestrial biosphere, Geophys. Res. Lett., 32, L21408, doi:10.1029/2005GL024247, 2005.

Gerten, D., Schaphoff, S., and Lucht, W.: Potential future changes in water limitations of the terrestrial biosphere, Climatic Change, 80, 277-299, 2007.

Gerten, D., Rost, S., von Bloh, W., and Lucht, W.: Causes of change in 20th century global river discharge, Geophys. Res. Lett., 35, L20405, doi:10.1029/2008GL035258, 2008.

Gerten, D., Heinke, J., Hoff, H., Biemans, H., Fader, M., and Waha, K.: Global water availability and requirements for future food production, J. Hydrometeorol., 12, 885-899, 2011.

Gerten, D., Hoff, H., Rockström, J., Jägermeyr, J., Kummu, M., and Pastor, A.: Towards a revised planetary boundary for consumptive freshwater use: role of environmental flow requirements, Curr. Opin. Env. Sust., submitted, 2013.

Gimeno, L., Stohl, A., Trigo, R. M., Dominguez, F., Yoshimura, K., Yu, L., Drumond, A., Durán-Quesada, A. M., and Nieto, R.: Oceanic and terrestrial sources of continental precipitation, Rev. Geophys., 50, 1-41, 2012.
Gleick, P. H.: The changing water paradigm - a look at twenty-first century water resources development, Water Int., 25, 127-138, 2000.

Gordon, L. J., Steffen, W., Jonsson, B. F., Folke, C., Falkenmark, M., and Johannessen, A.: Human modification of global water vapour flows from the land surface, P. Natl. Acad. Sci. USA, 102, 7612-7617, 2005.

Groenfeldt, D. and Schmidt, J. J.: Ethics and water governance, Ecol. Soc., 18, 14, doi:10.5751/ES-04629-180114, 2013.

Haddeland, I., Clark, D. B., Franssen, W., Ludwig, F., Voß, F., Arnell, N. W., Bertrand, N., Best, M., Folwell, S., Gerten, D., Gomes, S., Gosling, S. N., Hagemann, S., Hanasaki, N., Harding, R., Heinke, J., Kabat, P., Koirala, S., Oki, T., Polcher, J., Stacke, T., Viterbo, P., Weedon, G. P., and Yeh, P.: Multimodel estimate of the global terrestrial water balance: setup and first results, J. Hydrometeorol., 12, 869-884, 2011.

Hanasaki, N., Inuzuka, T., Kanae, S., and Oki, T.: An estimation of global virtual water flow and sources of water withdrawal for major crops and livestock products using a global hydrological model, J. Hydrol., 384, 232-244, 2010.

Hemming, D., Buontempo, C., Burke, E., Collins, M., and Kaye, N.: How uncertain are climate model projections of water availability indicators across the Middle East?, Philos. T. A Math. Phys. Eng. Sci., 368, 5117-5135, 2010.

Hickler, T., Smith, B., Prentice, I. C., Mjöfors, C., Miller, P., Arneth, A., and Sykes, M. T.: $\mathrm{CO}_{2}$ fertilization in temperate FACE experiments not representative of boreal and tropical forests, Global Change Biol., 14, 1531-1542, 2008.

Hoekstra, A. Y. and Mekonnen, M. M.: The water footprint of humanity, P. Natl. Acad. Sci. USA, 109, 3232-3237, 2012.

Hoff, H.: Understanding the Nexus, Background Paper for the Bonn 2011 Conference: The Water, Energy and Food Security Nexus, Stockholm Environment Institute, Stockholm, 2011.

Hutjes, R. W. A., Kabat, P., Running, S. W., Shuttleworth, W. J., Field, C., Bass, B., da Silva Dias, M. F., Avissar, R., Becker, A., Claussen, M., Dolman, A. J., Feddes, R. A., Fosberg, M., Fukushima, Y., Gash, J. H. C., Guenni, J., Hoff, H., Jarvis, P. G., Kayana, I., Krenke, A. N., Liu, C., Meybeck, M., Nobre, C. A., Oyebande, L., Pitman, A., Pielke Sr., R. A., Raupach, M., Saugier, B., Schulze, E. D., Sellers, P. J., Tenhunen, J. D., Valentini, R., Victoria, R. L., and Vörösmarty, C. J.: Biospheric aspects of the hydrological cycle, J. Hydrol., 212, 1-21, 1998.

Huntingford, C., Zelazowski, P., Galbraith, D., Mercado, L. M., Sitch, S., Fisher, R., Lomas, M., Walker, A. P., Jones, C. D., Booth, B. B. B., Malhi, Y., Hemming, D., Kay, G., Good, P., Lewis, S. L., Phillips, O. L., Atkin, O. K., Lloyd, J., Gloor, E., Zaragoza-Castells, J., Meir, P., Betts, R., Harris, P. P., Nobre, C., Marengo, J., and Cox, P. M.: Simulated resilience of tropical rainforests to $\mathrm{CO}_{2}$-induced climate change, Nat. Geosci., 6 , 268-273, 2013.

Immerzeel, W. W. and Bierkens, M. F. P.: Asia's water balance, Nat. Geosci., 5, 841-842, 2012.

Ito, A. and Inatomi, M.: Water-use efficiency of the terrestrial biosphere: a model analysis focusing on interactions between the global carbon and water cycles, J. Hydrometeorol., 13, 681-694, 2012.

Jasechko, S., Sharp, Z. D., Gibson, J. J., Birks, S. J., Yi, Y., and Fawcett, P. J.: Terrestrial water fluxes dominated by transpiration, Nature, 496, 347-350, 2013. 
Jevons, W. S.: The Coal Question, Macmillan \& Co., London, 1866. Jung, M., Reichstein, M., Ciais, P., Seneviratne, S. I., Sheffield, J., Goulden, M. L., Bonan, G., Cescatti, A., Chen, J., de Jeu, R., Dolman, A. J., Eugster, W., Gerten, D., Gianelle, D., Gobron, N., Heinke, J., Kimball, J., Law, B. E., Montagnani, L., Mu, Q., Mueller, B., Oleson, K., Papale, D., Richardson, A. D., Roupsard, O., Running, S., Tomelleri, E., Viovy, N., Weber, U., Williams, C., Wood, E., Zaehle, S., and Zhang, K.: Recent decline in the global land evapotranspiration trend due to limited moisture supply, Nature, 467, 951-954, 2010.

Katul, G., Porporato, A., and Oren, R.: Stochastic dynamics of plant-water interactions, Annu. Rev. Ecol. Evol. Syst., 38, 767791, 2007.

Keenan, T. F., Hollinger, D. Y., Bohrer, G., Dragoni, D., Munger, J. W., Schmid, H. P., and Richardson, A. D.: Increase in forest water-use efficiency as atmospheric carbon dioxide concentrations rise, Nature, 499, 324-327, 2013.

Keys, P. W., van der Ent, R. J., Gordon, L. J., Hoff, H., Nikoli, R., and Savenije, H. H. G.: Analyzing precipitationsheds to understand the vulnerability of rainfall dependent regions, Biogeosciences, 9, 733-746, doi:10.5194/bg-9-733-2012, 2012.

Konikow, L. F.: Overestimated water shortage, Nat. Geosci., 6, p. 3, 2012

Konar, M., Hussein, Z., Hanasaki, N., Mauzerall, D. L., and Rodriguez-Iturbe, I.: Virtual water trade flows and savings under climate change, Hydrol. Earth Syst. Sci., 17, 3219-3234, doi:10.5194/hess-17-3219-2013, 2013.

Konzmann, M., Gerten, D., and Heinke, J.: Climate impacts on global irrigation requirements under $19 \mathrm{GCMs}$, simulated with a vegetation and hydrology model, Hydrolog. Sci. J., 58, 1-18, 2013

Krinner, G., Viovy, N., de Noblet-Ducoudré, N., Ogée, J., Polcher, J., Friedlingstein, P., Ciais, P., Sitch, S., and Prentice, I. C.: A dynamic global vegetation model for studies of the coupled atmosphere-biosphere system, Global Biogeochem. Cy., 19, GB1015, doi:10.1029/2003GB002199, 2005.

Leakey, A. D. B., Ainsworth, E. A., Bernacchi, C. J., Rogers, A., Long, S. P., and Ort, D. R.: Elevated $\mathrm{CO}_{2}$ effects on plant carbon, nitrogen, and water relations: six important lessons from FACE, J. Exp. Bot., 60, 2859-2876, 2009.

Leipprand, A. and Gerten, D.: Global effects of doubled atmospheric $\mathrm{CO}_{2}$ content on evapotranspiration, soil moisture, and runoff, Hydrolog. Sci. J., 51, 171-185, 2006.

Linton, J.: What is Water? The History of a Modern Abstraction, UBC Press, Vancouver, 2011.

Long, S. P., Ainsworth, E. A., Leakey, A. D. B., Nosberger, J., and Ort, D. R.: Food for thought: lower-than-expected crop yield stimulation with rising $\mathrm{CO}_{2}$ concentrations, Science, 312, 1918 1921, 2006

Luo, Y., Gerten, D., Weng, E., Zhou, X., Parton, W. J., Le Maire, G., Keough, C., Beier, C., Ciais, P., Dukes, J. S., Emmett, B. A., Hanson, P. J., Knapp, A., Linder, S., Nepstad, D., and Rustad, L.: Modelled interactive effects of precipitation, temperature, and $\mathrm{CO}_{2}$ on ecosystem carbon and water dynamics in different climatic zones, Global Change Biol., 14, 1986-1999, 2008.

McIntyre, B. D., Herren, H. R., Wakhungu, J., and Watson, R. T.: Agriculture at a Crossroads, in: International Assessment of Agricultural Science and Technology for Development: Global Report, Island Press, 2008.
McVicar, T. R., Roderick, M. L., Donohue, R. J., and Van Niel, T. G.: Less bluster ahead? Overlooked ecohydrological implications of global trends of terrestrial near-surface wind speeds, Ecohydrology, 5, 381-388, 2012.

Medlyn, B. E., Duursma, R. A., Eamus, D., Ellsworth, D. S., Prentice, I. C., Barton, C. V. M., Crous, K. Y., De Angelis, P., Freeman, M., and Wingate, L.: Reconciling the optimal and empirical approaches to modelling stomatal conductance, Global Change Biol., 17, 2134-2144, 2011.

Milly, P. C. D. and Dunne, K. A.: Macroscale water fluxes 2. Water and energy supply control of their interannual variability, Water Resour. Res., 38, 1206, doi:10.1029/2001WR000760, 2002.

Molden, D. (Ed.): Water for Food, Water for Life: A Comprehensive Assessment of Water Management in Agriculture, Earthscan, London, 2007.

Mueller, N. D., Gerber, J. S., Johnston, M., Ray, D. K., Ramankutty, N., and Foley, J. A.: Closing yield gaps through nutrient and water management, Nature, 490, 254-257, 2012.

Nemani, R. R., Keeling, C. D., Hashimoto, H., Jolly, W. M., Piper, S. C., Tucker, C. J., Myneni, R. B., and Running, S. W.: Climatedriven increases in global terrestrial net primary production from 1982 to 1999, Science, 300, 1560-1563, 2003.

Newingham, B. A., Vanier, C. H., Charlet, T. N., Ogle, K., Smith, S. D., and Nowak, R. S.: No cumulative effect of 10 years of elevated $\left[\mathrm{CO}_{2}\right]$ on perennial plant biomass components in the Mojave Desert, Global Change Biol., 19, 2168-2181, 2013.

Oki, T. and Kanae, S.: Virtual water trade and world water resources, Water Sci. Technol., 49, 203-209, 2004.

Peel, M. C. and McMahon, T. A.: Continental runoff: a qualitycontrolled global runoff data set, Nature, 444, p. E14, 2006.

Peel, M. C., McMahon, T. A., and Finlayson, B. L.: Vegetation impact on mean annual evapotranspiration at a global catchment scale, Water Resour. Res., 46, W09508, doi:10.1029/2009WR008233, 2010.

Piao, S., Friedlingstein, P., Ciais, P., de Noblet-Ducoudré, N., Labat, D., and Zaehle, S.: Changes in climate and land use have a larger direct impact than rising $\mathrm{CO}_{2}$ on global river runoff trends, $\mathrm{P}$. Natl. Acad. Sci. USA, 104, 15242-15247, 2007.

Piao, S., Sitch, S., Ciais, P., Friedlingstein, P., Peylin, P., Wang, X., Ahlström, A., Anav, A., Canadell, J. G., Cong, N., Huntingford, C., Jung, M., Levis, S., Levy, P. E., Li, J., Lin, X., Lomas, M. R., Lu, M., Luo, Y., Ma, Y., Myneni, R. B., Poulter, B., Sun, Z. Z., Wang, T., Viovy, N., Zaehle, S., and Zeng, N.: Evaluation of terrestrial carbon cycle models for their response to climate variability and to $\mathrm{CO}_{2}$ trends, Global Change Biol., 19, 2117 2132, 2013.

Pokhrel, Y. N., Hanasaki, N., Yeh, P. J.-F., Yamada, T. J., Kanae, S., and Oki, T.: Model estimates of sea-level change due to anthropogenic impacts on terrestrial water storage, Nat. Geosci., 5, 389-392, 2012.

Ponce Campos, G. E., Moran, M. S., Huete, A., Zhang, Y., Bresloff, C., Huxman, T. E., Eamus, D., Bosch, D. D., Buda, A. R., Gunter, S. A., Scalley, T. H., Kitchen, S. G., McClaran, M. P., McNab, W. H., Montoya, D. S., Morgan, J. A., Peters, D. P., Sadler, E. J., Seyfried, M. S., and Starks, P.J.: Ecosystem resilience despite large-scale altered hydroclimatic conditions, Nature, 494, 34952,2013 
Port, U., Brovkin, V., and Claussen, M.: The influence of vegetation dynamics on anthropogenic climate change, Earth Syst. Dynam., 3, 233-243, doi:10.5194/esd-3-233-2012, 2012.

Ripl, W.: Water: the bloodstream of the biosphere, Philos. T. Roy. Soc. Lond. B, 358, 1921-1934, 2003.

Rockström, J., Falkenmark, M., Karlberg, L., Hoff, H., Rost, S., and Gerten, D.: Future water availability for global food production: The potential of green water for increasing resilience to global change, Water Resour. Res., 45, W00A12, doi:10.1029/2007WR006767, 2009a.

Rockström, J., Steffen, W., Noone, K., Persson, Å., Chapin III, F. S., Lambin, E. F., Lenton, T. M., Scheffer, M., Folke, C., Schellnhuber, H. J., Nykvist, B., de Wit, C. A., Hughes, T., van der Leeuw, S., Rodhe, H., Sörlin, S., Snyder, P. K., Costanza, R., Svedin, U., Falkenmark, M., Karlberg, L., Corell, R. W., Fabry, V. J., Hansen, J., Walker, B., Liverman, D., Richardson, K., Crutzen, P., and Foley J. A.: A safe operating space for humanity, Nature, 461, 472-475, 2009b.

Rodríguez-Iturbe, I. and Porporato, A.: Ecohydrology of WaterControlled Ecosystems: Soil Moisture and Plant Dynamics, Cambridge University Press, Cambridge, 2007.

Rosenthal, D. M. and Tomeo, N. J.: Climate, crops and lacking data underlie regional disparities in the $\mathrm{CO}_{2}$ fertilization effect, Environ. Res. Lett., 8, 031001, doi:10.1088/1748-9326/8/3/031001, 2013.

Rost, S., Gerten, D., Bondeau, A., Lucht, W., Rohwer, J., and Schaphoff, S.: Agricultural green and blue water consumption and its influence on the global water system, Water Resour. Res., 44, W09405, doi:10.1029/2007WR006331, 2008a.

Rost, S., Gerten, D., and Heyder, U.: Human alterations of the terrestrial water cycle through land management, Adv. Geosci., 18, 43-50, doi:10.5194/adgeo-18-43-2008, 2008b.

Rost, S., Gerten, D., Hoff, H., Lucht, W., Falkenmark, M., and Rockström, J.: Global potential to increase crop production through water management in rainfed agriculture, Environ. Res. Lett., 4, 044002, doi:10.1088/1748-9326/4/4/044002, 2009.

Saatchi, S., Asefi-Najafabady, S., Malhi, Y., Aragao, L. E. O. C., Anderson, L. O., Myneni, R. B., and Nemani, R.: Persistent effects of a severe drought on Amazonian forest canopy, P. Natl. Acad. Sci. USA, 110, 565-570, 2013.

Scanlon, B. R., Jolly, I., Sophocleous, M., and Zhang, L.: Global impacts of conversions from natural to agricultural ecosystems on water resources: quantity versus quality, Water Resour. Res., 43, W03437, doi:10.1029/2006WR005486, 2007.

Schmitz, C., Lotze-Campen, H., Gerten, D., Dietrich, J. P., Biewald, A., Bodirsky, B., and Popp, A.: Blue water scarcity and the economic impacts of future agricultural trade and demand, Water Resour. Res., 49, 3601-3617, 2013.
Siebert, S. and Döll, P.: Quantifying blue and green water uses and virtual water contents in global crop production as well as potential production losses without irrigation, J. Hydrol., 384, 198217, 2010.

Sitch, S., Smith, B., Prentice, I. C., Arneth, A., Bondeau, A., Cramer, W., Kaplan, J. O., Levis, S., Lucht, W., Sykes, M. T., Thonicke, K., and Venevsky, S.: Evaluation of ecosystem dynamics, plant geography and terrestrial carbon cycling in the LPJ dynamic global vegetation model, Global Change Biol., 9, 161$185,2003$.

Steffen, W., Grinevald, J., Crutzen, P., and McNeill, J.: The Anthropocene: conceptual and historical perspectives, Philos. T. Roy. Soc. A, 369, 842-867, 2011.

Sterling, S. M., Ducharne, A., and Polcher, J.: The impact of global land-cover change on the terrestrial water cycle, Nat. Clim. Change, 3, 385-390, 2013.

Strengers, B. J., Müller, C., Schaeffer, M., Haarsma, R. J., Severijns, C., Gerten, D., Schaphoff, S., van den Houdt, R., and Oostenrijk, R.: Assessing 20th century climate-vegetation feedbacks of landuse change and natural vegetation dynamics in a fully coupled vegetation-climate model, Int. J. Climatol., 30, 2055-2065, 2010.

Tubiello, F. N., Amthor, J. S., Boote, K. J., Donatelli, M., Easterling, W., Fischer, G., Gifford, R. M., Howden, M., Reilly, J., and Rosenzweig, C.: Crop response to elevated $\mathrm{CO}_{2}$ and world food supply: a comment on "Food for thought ..." by Long et al., Science, 312, 1918-1921, 2006, Eur. J. Agron., 26, 215-223, 2007.

Vicente-Serrano, S. M., Gouveia, C., Camarero, J. J., Beguería, S., Trigo, R., López-Moreno, J. I., Azorín-Molina, C., Pasho, E., Lorenzo-Lacruz, J., Revuelto, J., Morán-Tejedo, E., and Sanchez-Lorenzo, A.: Response of vegetation to drought timescales across global land biomes, P. Natl. Acad. Sci. USA, 110, 52-57, doi:10.1073/pnas.1207068110, 2013.

Vörösmarty, C., Leveque, C., and Revenga, C.: Fresh water, in: Millennium Ecosystem Assessment: Ecosystems and Human WellBeing - Current State and Trends Assessment, Vol. 1, edited by: Hassan, R., Scholes, R., and Ash, N., Island Press, 165-207, 2005.

Zaehle, S. and Dalmonech, D.: Carbon-nitrogen interactions on land at global scales: Current understanding in modelling climate biosphere feedbacks, Curr. Opin. Environ. Sust., 3, 311-320, 2011.

Zhao, M. and Running, S. W.: Drought-induced reduction in global terrestrial net primary production from 2000 through 2009, Science, 329, 940-943, 2010.

Zhou, X., Sherry, R. A., An, Y., Wallace, L. L., and Luo, Y. Q.: Main and interactive effects of warming, clipping, and doubled precipitation on soil $\mathrm{CO}_{2}$ efflux in a grassland ecosystem, Global Biogeochem. Cy., 100, GB1003, doi:10.1029/2005GB002526, 2006. 